\title{
Comparative Evaluation of Inductively Coupled Plasma-Optical Emission Spectroscopy and Atomic Absorption Spectrophotometry for Determining DTPA-Extractable Micronutrients in Soils
}

\author{
MARGAM SUNITHA, KANWAR L. SAHRAWAT, \\ AND SUHAS P. WANI \\ International Crops Research Institute for the Semi-Arid Tropics (ICRISAT), \\ Patancheru, India
}

\begin{abstract}
A study was conducted for comparative evaluation of atomic absorption spectrophotometry $(A A S)$ and inductively coupled plasma-optical emission spectroscopy (ICP-OES) for determining extractable zinc $(\mathrm{Zn})$, copper $(\mathrm{Cu})$, manganese $(\mathrm{Mn})$, and iron $(\mathrm{Fe})$ in sixty diverse soil samples having a wide range in $\mathrm{pH}$ and organic carbon $(C)$. The results were significantly affected by the method of analysis and soil type but generally did not follow a definite trend. Results for extractable Fe in Alfisol samples were significantly greater when using ICP-OES than AAS; and the results for $\mathrm{Zn}, \mathrm{Cu}$, and $\mathrm{Mn}$ were not significantly different for the two methods. For Vertisol samples, the results for extractable $C u$ were significantly greater by ICP-OES than by AAS, whereas extractable Fe and Zn were significantly greater by AAS than by ICP-OES, and the results for Mn were not significantly different for the two methods. The results are discussed relative to soil type and differences in soil organic carbon and $\mathrm{pH}$ of the samples used in the study.
\end{abstract}

Keywords Alfisols, extractable $\mathrm{Fe}, \mathrm{Cu}, \mathrm{Mn}$, and $\mathrm{Zn}$, soil testing, Vertisol and associated soils

\section{Introduction}

On-farm survey of farmers' fields in the semi-arid regions of India for soil fertility evaluation by the ICRISAT (International Crops Research Institute for the Semi-Arid Tropics) and its partners during the past decade demonstrated that the soils not only are low in organic carbon $(\mathrm{C})$, used as a proxy for potentially available nitrogen $(\mathrm{N})$, and deficient in major nutrients, but that multiple deficiencies of sulfur and micronutrients are widespread, and these multinutrient deficiencies are holding back the productivity of farmers' fields. This conclusion is supported by the results of analysis of a large number of soil samples for fertility, and by the results of follow-up on-farm trials on the effect of balanced nutrient management as compared to farmer input treatment on the productivity of a wide range of food and oilseed crops (Sahrawat and Wani 2013).

Received 28 March 2014; accepted 24 July 2014.

Address correspondence to Kanwar L. Sahrawat, Patancheru 502 324, Andhra Pradesh, India. E-mail: k.sahrawat@ cgiar.org 
For a timely quality analysis of a large number of soil, plant, and grain samples in the ICRISAT analytical service laboratory, especially for extractable micronutrients in soil samples, we are at present using both atomic absorption spectrophotometry (AAS) and inductively coupled plasma (ICP)-optical emission spectrometry (OES).

Because the operating conditions, especially the temperature for AAS (operating temperature range is $2300-2900{ }^{\circ} \mathrm{C}$ ) and ICP-OES (operating temperature range is 8000-10000 K, ${ }^{\circ} \mathrm{C}=\mathrm{K}-273$ ), differ for the instruments, we hypothesized that the ICPOES-based method includes additional quantity of organically bound micronutrients such as zinc $(\mathrm{Zn})$, copper $(\mathrm{Cu})$, manganese $(\mathrm{Mn})$, and iron $(\mathrm{Fe})$ over and above that measured by AAS, using diethylenetriaminepentaacetic acid (DTPA) as an extractant (Lindsay and Norvell 1978) for determining extractable micronutrients.

The objective of this study therefore is to comparatively evaluate the AAS- and ICPOES-based methods for determining DTPA-extractable $\mathrm{Zn}, \mathrm{Cu}, \mathrm{Mn}$, and $\mathrm{Fe}$ in diverse soil samples having a wide range of $\mathrm{pH}$ and organic $\mathrm{C}$. The information on this aspect is important as it has implications for soil-test calibration and recommendations for micronutrient fertilization of crops in various production systems.

\section{Materials and Methods}

A total of sixty soil samples belonging to Vertisol and associated Vertic soils (thirty samples) and Alfisol soils (thirty samples) were selected from a collection of samples to capture largest diversity in soil $\mathrm{pH}$ and organic carbon (C) (Table 1). A few samples of Ultisols (at sample numbers $31-35$ and $43-45$ in Table 1) with $\mathrm{pH}$ in the acidic range were also included with the group of Vertisol and associated soils to capture a range in soil reaction.

Before use, the soil samples were crushed using a wooden hammer and passed through a 2-mm sieve. For organic $\mathrm{C}$ analysis, the soil samples were ground to pass through a $0.25-$ $\mathrm{mm}$ sieve. For analysis of the samples, soil $\mathrm{pH}$ was measured by a glass electrode using a soil-to-water ratio of 1:2; organic $\mathrm{C}$ was determined using the Walkley-Black method (Nelson and Sommers 1996). Extractable $\mathrm{Zn}, \mathrm{Cu}, \mathrm{Mn}$, and Fe were extracted by the DTPA (Lindsay and Norvell 1978), and these elements in the extracts were determined using AAS and ICP-OES. Three independent analyses were made for each micronutrient element analysis using AAS and ICP-OES.

The results were statistically analyzed for test of significance for the extractable micronutrient elements determined by AAS- and ICP-OES-based methods using the Genstat 13 statistical package (Ireland 2010).

\section{Results and Discussion}

The soils used in the study had a wide range in $\mathrm{pH}$ (4.7 to 9.8) and organic $\mathrm{C}$ contents $(0.10$ to $1.08 \%$ ) (Table 1). It is known that soil $\mathrm{pH}$ and organic $\mathrm{C}$ status of soils greatly influence extractable micronutrient elements (Black 1993).

The results on extractable $\mathrm{Zn}, \mathrm{Cu}, \mathrm{Mn}$, and $\mathrm{Fe}$ in soil samples belonging to Alfisols and Vertisols and associated Vertic soils are given in Tables 2 and 3. Statistical analysis of the results comparing the results for extractable $\mathrm{Zn}, \mathrm{Cu}, \mathrm{Mn}$, and $\mathrm{Fe}$ by the AAS and ICP-OES methods for the two soil types (Table 4) showed that the results on extractable micronutrient elements were significantly affected by the method used for analysis and the soil type but generally did not follow a definite trend.

For example, the results for extractable Fe in Alfisol samples were significantly greater by ICP-OES than that by AAS and the results for $\mathrm{Zn}, \mathrm{Cu}$, and $\mathrm{Mn}$ were not 
Table 1

Organic C (OC) and pH of soil samples of Alfisol $(\mathrm{n}=30)$ and Vertisol and associated $(\mathrm{n}=30)$ soils used in the study $(\mathrm{n}=60)$

\begin{tabular}{|c|c|c|c|c|c|}
\hline \multirow[b]{2}{*}{ Sample } & \multicolumn{2}{|c|}{ Alfisols } & \multirow[b]{2}{*}{ Sample } & \multicolumn{2}{|c|}{ Vertisols + Ultisols } \\
\hline & $\mathrm{pH}$ & $\mathrm{OC}(\%)$ & & $\mathrm{pH}$ & $\mathrm{OC}(\%)$ \\
\hline 1 & 5.4 & 0.27 & $31^{*}$ & 4.9 & 0.40 \\
\hline 2 & 5.0 & 0.10 & $32 *$ & 4.9 & 0.40 \\
\hline 3 & 5.3 & 0.12 & $33^{*}$ & 4.7 & 0.30 \\
\hline 4 & 8.2 & 0.43 & $34^{*}$ & 4.7 & 0.70 \\
\hline 5 & 5.1 & 0.70 & $35^{*}$ & 4.8 & 0.40 \\
\hline 6 & 5.3 & 0.10 & 36 & 5.5 & 0.60 \\
\hline 7 & 7.9 & 0.56 & 37 & 5.5 & 0.60 \\
\hline 8 & 8.1 & 0.40 & 38 & 5.4 & 0.50 \\
\hline 9 & 7.9 & 0.13 & 39 & 5.2 & 0.50 \\
\hline 10 & 6.9 & 0.53 & 40 & 5.7 & 0.30 \\
\hline 11 & 5.2 & 0.81 & 41 & 5.7 & 0.40 \\
\hline 12 & 7.9 & 0.10 & 42 & 5.4 & 0.30 \\
\hline 13 & 5.0 & 0.14 & $43^{*}$ & 4.8 & 0.25 \\
\hline 14 & 5.0 & 0.24 & $44^{*}$ & 4.8 & 0.60 \\
\hline 15 & 8.2 & 0.67 & $45^{*}$ & 4.8 & 0.51 \\
\hline 16 & 5.4 & 0.19 & 46 & 8.5 & 0.80 \\
\hline 17 & 4.9 & 0.65 & 47 & 8.5 & 0.81 \\
\hline 18 & 5.4 & 0.98 & 48 & 8.5 & 0.90 \\
\hline 19 & 5.4 & 1.08 & 49 & 8.5 & 0.43 \\
\hline 20 & 7.9 & 0.12 & 50 & 8.5 & 0.26 \\
\hline 21 & 8.2 & 0.56 & 51 & 8.8 & 0.10 \\
\hline 22 & 5.2 & 0.11 & 52 & 8.7 & 0.80 \\
\hline 23 & 7.9 & 0.05 & 53 & 8.6 & 0.82 \\
\hline 24 & 8.0 & 0.25 & 54 & 8.4 & 1.00 \\
\hline 25 & 6.9 & 0.49 & 55 & 8.4 & 0.8 \\
\hline 26 & 7.0 & 0.52 & 56 & 8.5 & 0.62 \\
\hline 27 & 6.8 & 0.61 & 57 & 9.8 & 0.93 \\
\hline 28 & 6.7 & 0.72 & 58 & 8.9 & 0.72 \\
\hline 29 & 6.7 & 0.55 & 59 & 8.5 & 0.75 \\
\hline 30 & 7.8 & 0.15 & 60 & 8.4 & 0.50 \\
\hline
\end{tabular}

*Ultisols.

significantly different by the two methods. For Vertisol and associated samples, the results for extractable $\mathrm{Cu}$ were significantly greater by ICP-OES than by AAS, whereas extractable $\mathrm{Fe}$ and $\mathrm{Zn}$ was significantly greater by AAS than by ICP-OES method; and the results for Mn were not significantly different by the two methods used (Table 4).

Among the soil characteristics that affect the amount of extractable micronutrients, $\mathrm{pH}$ and organic matter are considered important. With increase in soil $\mathrm{pH}$ above neutral range, the amount of extractable micronutrient elements decrease, and their amounts are greater in soils with $\mathrm{pH}$ in the acidic range (Black 1993). In practical terms, the deficiencies of micronutrients, especially those of $\mathrm{Zn}, \mathrm{Mn}$, and Fe, are indeed widespread in soils with 
Table 2

Comparative evaluation of AAS and ICP-OES for determining extractable $\mathrm{Zn}, \mathrm{Cu}, \mathrm{Mn}$, and $\mathrm{Fe}\left(\mathrm{mg} \mathrm{kg}^{-1}\right)$ in Alfisol soil samples $(\mathrm{n}=30)$

\begin{tabular}{|c|c|c|c|c|c|c|c|c|}
\hline \multirow[b]{2}{*}{ Sample } & \multicolumn{2}{|l|}{$\mathrm{Zn}$} & \multicolumn{2}{|c|}{$\mathrm{Cu}$} & \multicolumn{2}{|c|}{$\mathrm{Mn}$} & \multicolumn{2}{|c|}{$\mathrm{Fe}$} \\
\hline & ICP-OES & AAS & ICP-OES & AAS & ICP-OES & AAS & ICP-OES & AAS \\
\hline 1 & 0.42 & 0.41 & 1.68 & 1.60 & 62.88 & 100.70 & 26.45 & 26.74 \\
\hline 2 & 0.34 & 0.34 & 2.08 & 2.09 & 33.19 & 35.71 & 36.05 & 36.43 \\
\hline 3 & 0.32 & 0.32 & 2.03 & 2.03 & 28.41 & 28.85 & 37.19 & 37.94 \\
\hline 4 & 0.38 & 0.40 & 2.30 & 2.45 & 29.60 & 20.87 & 9.16 & 9.71 \\
\hline 5 & 0.31 & 0.31 & 2.14 & 1.89 & 28.97 & 29.87 & 36.28 & 37.12 \\
\hline 6 & 0.32 & 0.33 & 2.08 & 2.02 & 37.21 & 41.17 & 38.98 & 39.09 \\
\hline 7 & 0.43 & 0.46 & 3.77 & 3.79 & 42.08 & 64.00 & 14.64 & 15.80 \\
\hline 8 & 0.24 & 0.28 & 1.84 & 1.82 & 17.45 & 18.06 & 9.48 & 10.00 \\
\hline 9 & 0.34 & 0.37 & 0.69 & 0.67 & 10.68 & 10.33 & 4.68 & 4.93 \\
\hline 10 & 2.83 & 1.93 & 2.78 & 2.68 & 52.57 & 76.00 & 21.03 & 21.56 \\
\hline 11 & 3.77 & 3.93 & 7.14 & 6.58 & 73.33 & 114.00 & 239.95 & 15.33 \\
\hline 12 & 0.47 & 0.51 & 0.75 & 0.70 & 11.93 & 11.41 & 5.34 & 5.22 \\
\hline 13 & 0.33 & 0.35 & 2.04 & 2.03 & 33.85 & 37.12 & 41.11 & 41.28 \\
\hline 14 & 0.53 & 0.55 & 1.58 & 1.47 & 51.77 & 68.75 & 34.55 & 34.30 \\
\hline 15 & 0.80 & 0.85 & 4.66 & 4.67 & 22.86 & 23.89 & 56.06 & 2.70 \\
\hline 16 & 0.35 & 0.34 & 1.66 & 1.622 & 33.10 & 37.30 & 36.50 & 36.18 \\
\hline 17 & 5.75 & 6.25 & 2.73 & 5.59 & 66.40 & 71.50 & 237.00 & 227.5 \\
\hline 18 & 3.0 & 3.50 & 4.83 & 9.20 & 179.30 & 172.00 & 189.70 & 176.00 \\
\hline 19 & 4.5 & 4.75 & 5.75 & 8.80 & 187.70 & 183.50 & 180.20 & 158.25 \\
\hline 20 & 0.39 & 0.39 & 4.56 & 0.67 & 9.60 & 9.94 & 3.70 & 3.31 \\
\hline 21 & 0.46 & 0.49 & 4.74 & 1.90 & 18.53 & 20.11 & 9.57 & 9.32 \\
\hline 22 & 0.26 & 0.29 & 1.16 & 1.56 & 28.87 & 30.79 & 30.68 & 30.21 \\
\hline 23 & 0.38 & 0.42 & 0.57 & 0.59 & 8.68 & 8.82 & 3.60 & 3.36 \\
\hline 24 & 0.39 & 0.37 & 1.75 & 1.55 & 12.17 & 11.15 & 7.71 & 5.88 \\
\hline 25 & 2.46 & 2.02 & 2.40 & 2.17 & 48.20 & 56.00 & 17.03 & 14.95 \\
\hline 26 & 2.8 & 2.66 & 2.40 & 2.40 & 52.70 & 46.00 & 18.32 & 17.39 \\
\hline 27 & 3.1 & 2.78 & 2.50 & 2.41 & 46.70 & 35.20 & 17.60 & 16.80 \\
\hline 28 & 3.8 & 3.44 & 6.37 & 5.85 & 68.50 & 74.70 & 396.00 & 389.70 \\
\hline 29 & 1.96 & 1.82 & 9.37 & 8.50 & 200.40 & 168.50 & 250.50 & 234.50 \\
\hline 30 & 0.37 & 0.37 & 0.73 & 0.67 & 10.48 & 9.55 & 4.05 & 3.30 \\
\hline
\end{tabular}

$\mathrm{pH}$ in the alkaline range; and toxicity of micronutrient such as Mn to upland crops has been reported on soils with $\mathrm{pH}$ in the acidic range. Generally, the amounts of extractable micronutrients increase with increase in soil organic $\mathrm{C}$, but this effect is further affected and modified by other soil characteristics including soil pH (Black 1993; Takkar 1996; Fageria, Baligar, and Clark 2002).

Equally importantly, the method used for determining extractable micronutrient elements has implications for soil-test calibration and recommendation for micronutrient fertilization of crops (Sahrawat et al. 2012). Because most of the soil-test calibration 
Table 3

Comparative evaluation of AAS and ICP-OES for determining extractable $\mathrm{Zn}, \mathrm{Cu}, \mathrm{Mn}$, and $\mathrm{Fe}\left(\mathrm{mg} \mathrm{kg}^{-1}\right)$ in Vertisol and associated soil samples $(\mathrm{n}=30)$

\begin{tabular}{|c|c|c|c|c|c|c|c|c|}
\hline \multirow[b]{2}{*}{ Sample } & \multicolumn{2}{|l|}{$\mathrm{Zn}$} & \multicolumn{2}{|l|}{$\mathrm{Cu}$} & \multicolumn{2}{|c|}{$\mathrm{Mn}$} & \multicolumn{2}{|c|}{$\mathrm{Fe}$} \\
\hline & ICP-OES & AAS & ICP-OES & AAS & ICP-OES & AAS & ICP-OES & AAS \\
\hline 1 & 0.75 & 0.71 & 6.22 & 5.76 & 114.7 & 106.5 & 245.6 & 254.4 \\
\hline 2 & 0.65 & 0.65 & 6.265 & 5.89 & 119.7 & 111.2 & 210 & 218 \\
\hline 3 & 0.59 & 0.6 & 6.24 & 6.05 & 117.5 & 109.7 & 289.2 & 320.7 \\
\hline 4 & 0.65 & 0.64 & 6.7 & 6.53 & 83.7 & 77.7 & 312.2 & 359.2 \\
\hline 5 & 0.92 & 0.91 & 6.18 & 6.03 & 137.4 & 132.5 & 304.7 & 346.5 \\
\hline 6 & 1.19 & 1.18 & 5.47 & 5.33 & 167.9 & 161.2 & 156.5 & 165.2 \\
\hline 7 & 1.03 & 1.09 & 7.64 & 7.35 & 197.7 & 191 & 166.5 & 182.2 \\
\hline 8 & 0.7 & 0.7 & 7.13 & 7.04 & 151.9 & 137.2 & 164.7 & 180.7 \\
\hline 9 & 1.56 & 1.52 & 7.13 & 6.9 & 209.2 & 166.5 & 182.4 & 204.2 \\
\hline 10 & 1.81 & 1.75 & 6.17 & 6.09 & 186.2 & 145.4 & 142.3 & 149.7 \\
\hline 11 & 0.41 & 0.45 & 5.3 & 5.07 & 139.2 & 145 & 187.7 & 196.7 \\
\hline 12 & 0.55 & 0.56 & 6.64 & 6.23 & 121.5 & 127.5 & 316.8 & 349.7 \\
\hline 13 & 0.55 & 0.56 & 6.09 & 5.68 & 60.7 & 64.5 & 338.4 & 382.4 \\
\hline 14 & 0.5 & 0.5 & 6.78 & 6.22 & 74.9 & 78.45 & 341.4 & 373.7 \\
\hline 15 & 0.43 & 0.45 & 4.79 & 4.53 & 83.2 & 88.9 & 379.7 & 412.5 \\
\hline 16 & 1.29 & 1.37 & 2.87 & 2.95 & 15.25 & 16.27 & 42.2 & 41.49 \\
\hline 17 & 0.36 & 0.44 & 2.98 & 2.98 & 13.25 & 14.26 & 48 & 52.5 \\
\hline 18 & 0.43 & 0.5 & 2.25 & 2.23 & 11.5 & 12.66 & 27.7 & 32 \\
\hline 19 & 0.88 & 0.91 & 4.05 & 4.05 & 21.5 & 22.26 & 41.4 & 47.9 \\
\hline 20 & 0.32 & 0.42 & 1.88 & 1.89 & 23.5 & 24.12 & 17.9 & 20.2 \\
\hline 21 & 1.46 & 1.52 & 4.49 & 4.71 & 31 & 30.41 & 55 & 58.9 \\
\hline 22 & 1.24 & 1.33 & 4.13 & 4.31 & 22.5 & 22.9 & 49.7 & 54 \\
\hline 23 & 1.39 & 1.46 & 4.08 & 4.03 & 22.25 & 23.07 & 54 & 63.9 \\
\hline 24 & 3.61 & 3.77 & 4.29 & 4.33 & 20.5 & 21.18 & 74.6 & 72.6 \\
\hline 25 & 0.74 & 0.93 & 1.06 & 1.1 & 6.39 & 7.24 & 6.17 & 7.87 \\
\hline 26 & 0.33 & 0.51 & 1.36 & 1.33 & 10.67 & 11.45 & 9.09 & 10.37 \\
\hline 27 & 0.36 & 0.57 & 2.39 & 2.41 & 25.9 & 30.9 & 17.29 & 16.95 \\
\hline 28 & 0.88 & 1.07 & 1.89 & 1.95 & 11.26 & 12.61 & 45.5 & 44.9 \\
\hline 29 & 0.25 & 0.48 & 2.17 & 2.15 & 14.32 & 15.99 & 17.85 & 20.12 \\
\hline 30 & 0.23 & 0.41 & 1.29 & 1.33 & 14.37 & 16.12 & 8.05 & 9.47 \\
\hline
\end{tabular}

and recommendations are generally based on the use of AAS for determining extractable micronutrients in soils and the use of ICP is rather recent in developing countries including India, our earlier results on the comparative evaluation of ICP and colorimetric methods for determining extractable sulfur (S) and boron (B) in soils also emphasized the need for such research on the calibration and revision of the recommendations accordingly using ICP-based methods for the analysis of extractable micronutrients in soils (Sahrawat et al. 2012; Shirisha et al. 2010).

To conclude, the results of our study on the comparative evaluation of AAS and ICP-OES methods suggest that the results of extractable $\mathrm{Zn}, \mathrm{Cu}, \mathrm{Mn}$, and $\mathrm{Fe}$ in soils are 
Table 4

Statistical analysis of the results on extractable $\mathrm{Zn}, \mathrm{Cu}, \mathrm{Mn}$, and $\mathrm{Fe}\left(\mathrm{mg} \mathrm{kg}^{-1}\right)$ in Vertisol and associated and Alfisol soil samples

\begin{tabular}{lccccc}
\hline Soil type & Element & ICP-OES & AAS & Probability & Test of significance \\
\hline Vertisol $(\mathrm{n}=30)$ & $\mathrm{Zn}$ & 0.87 & 0.93 & 0.0002 & $* *(P<0.001)$ \\
& $\mathrm{Cu}$ & 4.53 & 4.41 & 0.0026 & $*(P<0.05)$ \\
& $\mathrm{Mn}$ & 74.3 & 70.8 & 0.1076 & $\mathrm{NS}$ \\
Alfisol $(\mathrm{n}=30)$ & $\mathrm{Fe}$ & 141.7 & 154.9 & 0.0001 & $(P<0.05)$ \\
& $\mathrm{Zn}$ & 1.39 & 1.37 & 0.6845 & $\mathrm{NS}$ \\
& $\mathrm{Cu}$ & 2.91 & 2.99 & 0.5013 & $\mathrm{NS}$ \\
& $\mathrm{Mn}$ & 49.9 & 53.8 & 0.1241 & $\mathrm{NS}$ \\
& $\mathrm{Fe}$ & 67.1 & 64.7 & 0.0278 & $(P<0.05)$ \\
\hline
\end{tabular}

${ }^{*}$ Significant.

${ }^{* *}$ Highly significant.

NS, not significant.

significantly affected by soil type ( $\mathrm{pH}$ and organic $\mathrm{C}$ status) and the method used for determining micronutrient elements. These results have implications for soil-test calibration and recommendation for micronutrient fertilization of crops.

\section{References}

Black, C. A. 1993. Soil fertility evaluation and control. Boca Raton, FL: Lewis Publishers.

Fageria, N. K., V. C. Baligar, and R. B. Clark. 2002. Micronutrients in crop production. Advances in Agronomy 77: 185-268. doi:10.1016/S0065-2113(02)77015-6

Ireland, C. 2010. Experimental statistics for agriculture and horticulture. Wallingford, UK: CABI.

Lindsay, W. L., and W. A. Norvell. 1978. Development of a DTPA soil test for zinc, iron, manganese, and copper. Soil Science Society of America Journal 42: 421-28. doi:10.2136/sssaj1978.03615995004200030009x

Nelson, D. W., and L. E. Sommers. 1996. Total carbon, organic carbon, and organic matter. In Methods of soil analysis, part 3: Chemical methods, ed. D. L. Sparks, 961-1010. Madison, WI: SSSA and ASA.

Sahrawat, K. L., K. Shirisha, K. V. S. Murthy, P. N. Gajbhiye, S. Kundu, S. P. Wani, and G. Pardhasaradhi. 2012. Comparative evaluation of inductively coupled plasmaatomic emission spectroscopy and colorimetric methods for determining hot-water-extractable boron in soils. Communications in Soil Science and Plant Analysis 43: 948-57. doi:10.1080/00103624.2012.653030

Sahrawat, K. L., and S. P. Wani. 2013. Soil testing as a tool for on-farm fertility management: Experience from the semi-arid zone of India. Communications in Soil Science and Plant Analysis 44: 1011-32. doi:10.1080/00103624.2012.750339

Shirisha, K., K. L. Sahrawat, K. V. S. Murthy, S. P. Wani, P. N. Gajbhiye, and S. Kundu. 2010. Comparative evaluation of ICP-AES and turbidimetric methods for determining extractable sulfur in soils. Journal of the Indian Society of Soil Science 58: 323-26.

Takkar, P. N. 1996. Micronutrient research and sustainable agricultural productivity. Journal of the Indian Society of Soil Science 44: 563-81. 
Copyright of Communications in Soil Science \& Plant Analysis is the property of Taylor \& Francis Ltd and its content may not be copied or emailed to multiple sites or posted to a listserv without the copyright holder's express written permission. However, users may print, download, or email articles for individual use. 